\title{
Living currency: The multiple roles of livestock in livelihood sustenance and exchange in the context of rural indigenous communities in southern Africa
}

\author{
Soul Shava, University of South Africa, and Sibongile Masuku, \\ Sol Plaatje University, South Africa
}

\begin{abstract}
Modern national and international monetary currencies continue to be the accepted universal media of exchange globally and, to a large extent, have expanded and displaced indigenous currencies and their roles within some community settings. There are, however, areas where indigenous currencies such as livestock (see Schneider, 1964), are considered as the most significant aspect of traditional economies. This paper explores the past and present roles of livestock as indigenous living currency amongst the Nguni and Shona people of southern Africa, mainly drawn from collaborative autoethnography. It further highlights how livestock currencies used alongside monetary ones have sustained and created multifaceted livelihood strategies of such rural area dwellers through intergenerational learning processes. This is against the background of the global economic instability ushered forth by modern economic practices (Karmin, 2008). The paper suggests that traditional 'living' currencies provide a more sustainable economy that enhances the socio-ecological resilience of indigenous rural communities in southern Africa. It also emphasises the need to recognise the coexistence of plural economies beyond the current monopoly of modern capitalist monetary economies.
\end{abstract}

\section{Introduction}

One common feature among the Bantu people of southern Africa was(is) their agro-pastoral livelihoods, particularly how they value(d) livestock and use(d) it as a medium of exchange in trade and other social activities within the Nguni and Shona community contexts. Mixed herds of various forms of livestock are kept, including cattle, sheep, goats and chickens. Animals are ranked according to their value, determined by the extent of their multiple uses. Among these different types of livestock, cattle are regarded as the most important by most indigenous communities (Ainslie, 2002), followed by goats and sheep, then fowls; and, in each species, females are more valued due to their reproductive capacity, while young animals of breeding age are more valued than old animals.

In this paper, the multifunctional role of livestock among the Nguni and Shona people in southern Africa is explored. The Shona comprise a group of people with diverse but related language dialects who comprise the majority of the people of Zimbabwe. In the northern part along the Zambezi Valley are the people of the Korekore dialect, the central part is occupied by the Zezuru dialect-speaking people, to the east are the people of the Manyika dialect (who also occupy the western part of Mozambique), to the southeast are people of the Ndau dialect 
(who also spill over into Mozambique), the Masvingo province to the south is occupied by people of the Karanga dialect, while the Kalanga occupy the southwestern part of Zimbabwe (Matebeleland South), mainly dominated by the Ndebele-speaking people (see Gelfand, 1973, 1979; Gwaravanda \& Masaka, 2008a, 2008b). The focus on use of livestock in Zimbabwe was explored among the Korekore dialect-speaking people in Hurungwe. The Nguni-speaking people mainly comprise people of the Ndebele, Shangaan, Swathi, Xhosa and Zulu dialects in southern Africa (Mphande, 1993; Huffman, 2004). The Ndebele occupy the western part of Zimbabwe (Matebeleland North and South) and the northern part of South Africa (the so-called southern Ndebele); the Zulu mainly occupy the area of KwaZulu-Natal, South Africa; the Xhosa are found mainly in the Eastern Cape and Western Cape, South Africa; the Shangaan are found in the Limpopo Province, southern Zimbabwe and Mozambique; while the Swati are found mainly in Swaziland and Mpumalanga Province of South Africa. The Nguni, or Ngoni, also extend into Malawi and Tanzania.

For indigenous communities, livestock was(is) not only a means of subsistence but was(is) interwoven into different aspects of people's everyday lives. It has also signified wealth and food security. Most indigenous peoples have been forcibly incorporated into the global capitalist monetary economy. In indigenous rural communities, livestock are an alternative currency that fills the role that money has in modern capitalist economies (Schneider, 1964). The manner in which cattle, goats and chicken were(are) looked after displayed and continues to display the existence of a complex relationship between the livestock, homestead subjects, their belief systems and socio-ecological becoming. Livestock had and still has social, economic, political, spiritual, as well as ecological significance (see Makamure, 1970; Park, 2013;Tsodzo, 1970). This is not only the case with the Shona and Nguni people who are the subject of this paper, but also with other indigenous cultural groupings such as the Tswana in southern Africa. Comaroff and Comaroff (1990:195) describe what cattle meant amongst the Batswana:

They linked processes of production and exchange, embodied an order of meanings and relations, and had the capacity to reproduce a total social world. They were, in sum, prime media for the creation and representation of value in a material economy of persons and a social economy of things. But they also had particular historical salience.

The problem that this research addresses is embedded in the observation that money is often the focal point of modern-day life, but it has less significance in the everyday lives of indigenous peoples compared to the livestock upon which their livelihoods are largely dependent. Most of the indigenous communities that are considered 'poor' in modern western capitalist monetary terms survive on a thriving alternative non-monetary economy based on a multifunctional and living indigenous currency in the form of their livestock. This is more so compared to the instability of the monetary currency which can be suddenly eroded with major implications for the families' livelihood sustenance and future security. The multiple roles of livestock as living currency within indigenous communities is explored drawing from our lived experiences as community members within the Nguni and Shona peoples and drawing on literature from other researchers. Collaborative autoethnographical reflections of the authors and review of the 
literature were used as sources of data. The multiple uses of livestock species within indigenous communities were revealed, including their role as wealth, livelihood security, gifts, clothing (garments), traditional payment, trading currency, lobola/roora (dowry), and in spiritual rituals and ceremonies.

The findings reveal that indigenous livestock continue to be used as relevant living currencies among Shona and Nguni indigenous peoples and provide a more stable and holistic mode of exchange within these communities that ensures self-reliance. However, we acknowledge that environmental degradation, emerging environmental crises, such as climate change, industrialisation and rapid urbanisation, may pose challenges to livestock as indigenous currencies and their multiple roles within indigenous communities. In drawing attention to the presence of alternative economies to the dominant modern capitalist monetary economy, we argue for the need to rethink the conventional perception of an economy as being modern, capitalist and monetary and to embrace the coexistence of plural economies.

A description of the research approach, the emerging narratives and ensuing discussions and conclusions will be dealt with consecutively.

\section{Research methodology}

We (Masuku, 1999, 2018; Shava 2000, 2008) have worked on indigenous knowledges as peripherised knowledges over time, exploring their roles in environmental education processes. Our research interests have grown with the intention of further exposing the less-recognised understandings that are generated within indigenous community contexts, most particularly within rural settings. Intergenerational learning has a particular role (Masuku, 2018). In line with this background, this study draws on the decolonial research paradigm, as referred to in this article, in that it challenges the taken-for-granted capitalist monetary economic mode, which marginalises and excludes other economic systems. We affirm and bring attention to alternative non-monetary local economies that are both functional and sustainable in southern African indigenous community contexts. Decoloniality encompasses aspects of critical theory, postcolonial and anticolonial theory in that it aims to challenge the effects of imposed colonisation and continuing coloniality in the 'Global South' and to dismantle the hegemonic western/capitalist/Euro-North-Ameri-centric epistemologies, systems, processes and agendas through delinking from coloniality by shifting the geography of reason, the locus of enunciation, from the Global North to the Global South (Mignolo, 2011; Maldano-Torres, 2011). Decoloniality is therefore not confined by disciplines in its approach and its agenda is explicitly critical (a critique of coloniality) and transformative (the development of alternative models/perspectives). Decoloniality is both an epistemological and political movement (Ndlovu-Gatsheni, 2015); it is a continuous process of epistemic and political emancipation in which indigenous epistemologies, ontologies, pedagogies and practices play a central role. Decoloniality is reflected in a growing body of research by indigenous scholars from South America, the Caribbean, New Zealand, Australia, Samoa, Hawaii, North America, Northern Europe, Africa and Asia, among others. In reference to ecologies of knowledge, De Sousa Santos argues that modern western knowledge is based on abyssal thinking in which modern 
scientific knowledge (in this case modern western economics) is 'given monopoly of universal distinction between true and false, to the detriment of alternative knowledges' (De Sousa Santos, 2007:47). Alternative knowledges such as indigenous knowledges are deemed as non-existent (made invisible) and excluded in many modern western knowledge discourses because they do not conform to the western frame of thinking. The marginalisation and exclusion of indigenous knowledges by colonising and hegemonic western/modern/EuroNorth-Ameri-centric knowledge discourses and its prevailing negative impacts on indigenous peoples across all spheres of their lives (including their knowledge, pedagogies, languages, lands, resources, economies, histories, politics/sovereignty (rights and freedoms), spirituality, cultures and practices) have been noted by many indigenous scholars (including Dei, 2000; Dei, Hall \& Rosenberg, 2002; Masuku van Damme \& Neluvhalani, 2004; Shava 2000, 2008, 2013, 2016; Shiva 1993; Smith, 1999). This includes the marginalisation of indigenous modes of economy that do not conform to the modern capitalist monetary economy.

As a process of rupturing the hegemony of modern conventional monetary economic models through an 'insurrection of subjugated knowledges' (Foucault, 1980:81), this article posits that there are resilient and sustainable African-centred alternatives to modern capitalist economic systems that are a living reality within indigenous community contexts, and that these two economic systems coexist, thereby alluding to the plurality of economic systems and knowledge systems in general (Shava, 2013). Interestingly, whenever an economy is selfsustaining and does not conform to capitalist modes of production and monetary currencies, it is relegated to a subsistence economy.

This article is mainly a narrative account that is drawn from our lived experiences growing up and researching in indigenous Nguni and Shona communities that have been corroborated and expanded through informal discussions or interviews with elderly members of our extended families in Zimbabwe (Mashonaland West) and Swaziland. This approach aligns to collaborative autoethnography, which is defined by Chang, Ngunjiri and Hernandeze (2013:17) as 'a qualitative research method that is simultaneously collaborative, autobiographical and ethnographic'. We found this approach a suitable way to narrate our lived experiences on the various uses of livestock. A mixture of planned and random informal discussions/interviews were mainly held with elderly family members from Zimbabwe (three males and two females from Hurungwe, Mashonaland West) during a stay of one month by one of the authors in Zimbabwe in 2016, who were purposively selected due to their possession of livestock and knowledge of them. Most of the discussions turned into informal focus group discussions as other family members would also add their knowledge and views on aspects that were asked about as this usually happened within family everyday activities, such as doing chores around the homestead or sharing a meal, in order to not break the usual flow of activities. Consent was sought and obtained to voice-record the discussions. Member-checking was continuously done by going over summaries of what had been previously discussed, which at times led to additional views and insights. Information was also drawn from a critical ethnographic research project undertaken in rural KwaZulu-Natal. In this area, interviews were held with community members (40 community members with ages ranging from six to 80 years) in Mpembeni, KwaZulu-Natal, as part of broader doctoral research project by one of the authors spanning 
three years (2015-2017) with several one-month periods of stay within the community (Masuku, 2018). Interestingly, a similar approach of a combination of planned as well as random chance interviews with knowledgeable community members was employed. Prior informed consent, confidentiality and respect were key ethical considerations during the research process.

The interview data was transcribed, translated (from chiShona and isiZulu into English), member-checked and analysed through coding and sorting into emerging themes. The results were corroborated (triangulated) with our own lived experiences and observations growing up and researching in rural contexts. The resultant thematic narratives discussed below are supported with reference to reviewed literature within the public domain.

\section{Living currencies}

The transactional, communal and family uses of livestock and their products vary from one community to another. Based on research data and our lived experiences, and supported by reviewed literature, the emerging uses of livestock as indigenous currencies within indigenous Shona and Nguni cultures are discussed below. We refer to livestock as living currencies because they represent a living mode of exchange.

\section{Livestock as wealth}

Within traditional community settings, livestock has always signified the wealth of a man who would jealously guard it as the head of the family as well as instruct others on its upkeep and slaughter (except on trade-related transactions). The larger the head of the family's herds were, the more respect he garnered locally and beyond. This was not solely because of his wealth but also because of his breadth of knowledge, skills and experience, particularly about livestock health, reproduction and upkeep. Attributing his wealth to knowledge meant that he was broadly consulted for this knowledge. However, the advent of colonialism and the imposition of different forms of taxation on homestead members and their domesticated animals altered such practices and associated processes. Men were compelled to migrate from their rural communal areas to take up manual labour tasks that serviced colonialism, such as those generated by the emerging mineral revolution (Magubane, 1986). This warranted the transferral of some of the responsibilities related to the care of livestock to women, who had to take on more responsibilities for everyday sustenance. For women, livestock roles were more restricted to goats, chickens and pigs, and cattle remained the domain of men who were consulted over issues relating to them. With the onset of industrialisation in southern Africa, many men went to work in mines and factories to make money (ukusebenza/ukuphangela (Nguni)/kuenda kumarimuka (Shona)) so that they could go back to their villages and purchase cattle as wealth. This signified an interface between the modern capitalist economy and the indigenous economy in which both coexisted and had reciprocal valuation.

Comaroff and Comaroff (1990:195) consider cattle as a complex-to-define commodity that fluidly resides in the 'in betweens' of modernity and practices of the past: 'The double character of cattle - as icons of a "traditional" order and as weapons in the struggle to assert control over modern life - has significant implications for our understanding of commodities in 
non-capitalist, non-European contexts' . The Comaroffs describe money from the community perspective as 'cattle without legs' (1990:195). This description is consistent with how livestock - and, more particularly, cattle as the most valued of livestock - are considered in this paper. Livestock differ from money in that they are a living source of wealth that reproduces naturally and are not affected by economic fluctuations. Livestock remain a key survival strategy for many rural communities.

Historically, livestock were passed on as an inheritance from the father to the children, and therefore the practice of children looking after livestock was in reality children looking after their inheritance (pfuma (Shona)/ilifa (Nguni)). Looking after livestock was therefore an intergenerational learning process (Masuku, 2018). Cattle were central to the valuation of one's wealth and social status (Bere-Chikara, 1970; Guy, 1987; Tsodzo, 1970). The importance of cattle is more significant in the culture of some agro-pastoral ethnic groups that place less emphasis on crops, such as the amaZulu, emaSwati and amaNdebele. In the worldview of the community, the value of livestock as wealth is not equated to their monetary/exchange value but to their symbolic value as wealth in themselves (see Doran, Low \& Kemp, 1979).

The value of livestock as wealth has been the cause of many wars among the Bantu ethnic groups. Amassing livestock brought men great honour and respect such that some warring tribes, including the Zulu and the Ndebele, have been well known for their cattle raiding activities. The number of cattle that an ethnic group had/has signified political and economic power (Oosthuizen, 1996).

\section{Livestock as livelihood security}

Livestock are crucial to the livelihoods of many rural communities in southern Africa and cushion them against risks and vulnerability (Freeman, Kaitibe, Moyo \& Perry, 2008). This is more so for communities that live in arid and semi-arid areas of southern Africa where cropping is unreliable, such as in Botswana where livestock rearing is a key economic activity. Besides providing meat, by-products from livestock, such as milk and eggs, are also valuable sources of food (Bere-Chikara, 1970; Dore, 1970; Tsodzo, 1970) and other products (hides, feathers, etc.). Milk (ubisi/uchago (Nguni)/mukaka (Shona)) was/is usually fermented and made into several products, including: buttermilk (amasi (Nguni)/mukakaka wakakora (Shona)); cream (ulaza (Nguni)/ruomba (Shona)); whey (ulaza (Nguni); and umfuma (Nguni) - a fragrant beauty ointment derived from cream mixed with herbs. These multiple benefits fulfil the Shona proverb 'chirere chigokurerawo', meaning if you rear (look after) something it will also take care of you. The waste litter from livestock, such as dung (ndove (Shona)/ubulongwe (Nguni)), has been used as manure to fertilise the crop fields, thereby supporting crop production, and the more manure was available the richer the crop in the fields. In addition, dung was used in plastering the floors (Dore, 1970) and walls of huts in the homestead (kudzira nendove (Shona)/ukusinda ngobulongwe (Nguni)), thereby making them more structurally secure. Cattle were also used as draught power, providing traction with the advent of the ox-drawn plough, sledge and cart. This cyclical flow of resources is environmentally friendly compared to commercial, capitalistic, inorganic chemical-intensive agricultural systems.

Livestock provide a more reliable livelihood resource. Unlike crops - which are susceptible to extreme weather conditions such as drought - livestock such as cattle, goats and sheep 
provide the added advantage to the home in that they are naturally grazed or browsed and can be moved way from areas of drought and shortage of grazing/browsing to other more suitable forage sites. This livestock mobility is probably linked to the origin of pastoral communities in Africa. Livestock can thus be maintained sustainably through migration patterns and are therefore a more dependable source of livelihood. Hall (1986:86) argues that:

Cattle were more important to farmers because they were a more consistent resource than agricultural produce, and livestock were kept in increasing numbers not because of any adherence to a necessary dynamic of history but because livestock enabled the farmer to insure against future adversity and to establish more secure networks of reciprocity with other households.

The Bantu people had different indigenous breeds of livestock specifically adapted to their local lived environments, thereby enhancing the sustenance of the livestock (see Mwai, Hanotte, Kwon \& Cho, 2015; Oosthuizen, 1996). For example, the vaShona have their Shona (so-called Hard Mashona type) cattle, the amaNdebele have their Tuli cattle, while the amaZulu and emaSwati have their Nguni (originally Zulu or Swazi) breeds of cattle. Similarly, indigenous breeds of chickens, goats and sheep are well adapted to local environments. This reveals the extent of livestock agro-biodiversity in the southern African region and its importance to livelihood security due to its adaptation to local environmental conditions.

\section{Livestock as gifts}

A common token of appreciation was in the form of livestock (cattle, chickens, sheep or goats). This could be done in appreciation of a service rendered or as a farewell gift to a guest. When a home receives visitors, it is common practice to slaughter a chicken, goat, sheep or calf for them, depending on the livestock wealth of the homestead. A parent would normally give a hen, she-goat, ewe or heifer to a child in order to try their hand in livestock husbandry. Favourite nephews, nieces and grandchildren would also receive gifts of livestock to take back with them when they visited members of the extended family. Gifting children with livestock teaches them aspects of valuing, responsibility and caring for them (Jimenez, 2015). Responsibility for livestock starts with smaller livestock until the children graduate to care and own bigger ones.

\section{Livestock as a source of clothing}

Most traditional clothing was made from hides prior to the introduction of cotton, wool and other natural and synthetic clothing materials. The hides (isikhumba isigogo (Nguni)/ganda (Shona)), mainly derived from livestock, were traditionally processed or tanned (ukutshuka isikhumba (Nguni)/kunyika ganda (Shona)) until they were soft enough to be fashioned into traditional clothing (izigqoko/amabhetshu/izidwaba/imisisi (Nguni)/nhembe (Shona)) and sleeping mats or blankets (ingubo (Nguni)/nguwo yekufuka (Shona)).

\section{Livestock as trading currency}

Traditionally livestock have been exchanged in trade transactions for other valuable goods and commodities (Tsodzo, 1970). These include grain, tools and implements (iron axes, hoes, 
spears, etc.) as well as modern imported clothing and ornaments (beads) that were traded at trading sites such as Mapungubwe and Great Zimbabwe (see Hall, 1986). Livestock therefore comprised a significant aspect of the material culture of indigenous peoples of southern Africa.

In the modern era, rural communities that still rely on livestock can convert livestock to money when the need arises by selling off some of their animals. However, they still hold on to livestock as wealth due to its multiple functions. The exchange of livestock for modern currency symbolises the zone of transition between the indigenous economy (modes of exchange) and the modern economy, alluding to the coexistence of both economies within indigenous communities.

\section{Livestock as payment (muripo, inhlawulo)}

Livestock has been used as the main currency of payment in customary law (traditional governance systems) to pacify the offended and to punish the offender (see Bere-Chikara, 1970; Makamure, 1970). The gravity of the case/crime brought to the court (dare (Shona)/inkudla (Nguni)) determines the type of livestock used in payment of a fine (muripo (Shona)/inhlawulo (Nguni)) by the perpetrator to satisfy the aggrieved. In these traditional court settlements, the lowest-ranking case would be paid by chickens while the heavier cases were to be paid with herds of cattle. Some cases are not brought to the court but are likewise settled at the extended family level, such as grievances between couples, between family members or between parents and children. For example, among the Shona and Nguni, fines in the form of cows were paid to promote celibate relationships - in the event that a girl is impregnated, the boy responsible has to pay a fine to restore the dignity of the girl. Livestock have therefore played an important mediating role in family and community interrelationships.

\section{Livestock as dowry (jeredzwa, roora, amalobolo)}

In the traditional marriage institution, ilobolo (Nguni) or roora/jeredzwa (Shona) was a symbolic appreciation of the bride and respect (ukuhlonipa abakwabozala (Nguni)/kuremekedza tezvara naambuya (Shona)) through cattle given to the father and mother of the bride by the son-in-law. When the groom's family and messengers (umthunywa (Nguni)/munyai (Shona)) came to ask for a wife (kukumbira mukadzi (Shona)/ukucela umfazi/umlilo (Nguni) - a wife is associated with the fireplace (umlilo (Nguni)/fire) and bringing warmth and life to the home - the father of the groom and his family would state the amalobolo (the dowry in the form of cattle) they required from the bridegroom. The ability of the in-laws to pay amalobolo was symbolic of their ability and commitment to look after the bride and the children to be. Amalobolo therefore does not imply 'buying a wife' (Chireshe \& Chireshe, 2010; Gelfand, 1981; Mangena \& Ndlovu, 2013) as is normally misrepresented and misinterpreted in western writings (for example see Schneider, 1964). It instead signifies the cementation of a relationship between the families of the bride and that of the bridegroom, a process that is symbolised by umshado/umthimba (Nguni)/muchato (Shona) or the wedding feast, where beasts are slaughtered by the in-laws on both sides in celebration of the union of marriage. In traditional weddings, the process took several days, with events at both in-laws, amalobolo/roora on the one hand and the reception of the bride (kutambira muroora (Shona)/ukwamukela umakoti (Ndebele)) on the other. In these reception ceremonies 
gifts of livestock (fowls, goats, sheep and cattle), implements, utensils, food, among other things would be given to the bride and the groom to help them start their own home.

In the Shona culture, roora is not usually paid all at once as this will be considered a mockery to the father-in-law's family and a taboo. However, certain key aspects of the roora had to be paid before the bride was released in symbolic exchange, showing acceptance of the new son-in-law. These included mombe yeumai (the mother's cow, valued because it reproduces and gives milk) and mombe yedanga (the cow to start the kraal). It was usual for the married couple to set up a home away from their parents. The parents of the groom would occasionally send a messenger (nhumwa/munyai) to claim the outstanding bridal price when they wanted to see their son-in law, in which case the son-in-law and daughter will be obliged to pay them a visit. This signifies that the marriage union was not about 'buying the bride' but building relationships. There are therefore the sayings 'kuroora hakuperi' (Shona), meaning lobolo does not end, and 'mukwasha muonde haaperi kudyiwa' (Shona) - the son-in-law is a fig tree that continues to yield fruit. Lobolo also serves as a form of long-term security (insurance) for the family of the bride in times of need as they can make a claim to the son-in-law on the outstanding cattle.

In the past the father will provide cattle for the lobolo (inkomo zamalobolo/zamabheka (Nguni)/ mombe dekuroora/dzechimanda (Shona)) to the sons, representing a trans-generational transference of wealth, failing which the sons had to individually work and raise capital in order to be able to buy cattle for the lobolo. Up to today, the traditional marriage institution of lobola is still practised among indigenous people of southern Africa, signifying it as an important cultural heritage practice. The custom of lobolo is intended to safeguard marriage relationships against divorce (Bere-Chikara, 1970). However, ukulobola/kuroora (traditional marriage negotiation process) has been modernised with the onset of urbanisation, with livestock being replaced with money, bringing with it the negative connotations of 'buying a wife' and the commercialisation of the custom (see Mangena \& Ndlovu, 2013; Ngema, 2013). While some of the cattle in the dowry can be replaced with money, ritually there are some than cannot be exchanged with money and have to be presented as live cattle (mombe dzinotsika (Shona)/inkomo ezinyathelayo (Nguni)). These include mombe yeumai/yechimanda (Shona - the mother-in-law's cow) and mombe yedanga (Shona)/inkomo yesibaya (Nguni - the cow for the in-law's kraal).

\section{Livestock and spirituality}

The religious processes of speaking and giving to the ancestors involved the ritual sacrifice offering of livestock (ukunikela amadlozi (Nguni)/kupira mudzimu (Shona)). Livestock played a mediating role between the living and the ancestral shades. A chicken, goat, sheep or bull could be required of a person or family in order to connect with, or appease, the ancestors. Livestock therefore provided spiritual currency for connecting with the ancestors.

In the Nguni culture, particularly among the Xhosa, the cattle kraal (intlanti/isibaya (Nguni)/ danga (Shona)) served as a significant site for ritual activities (ukwenza umsebenzi) in the home, and a domain occupied by men. This reveals the importance of cattle in linking the living to the ancestors.

In most traditional homes, there was(is) a revered bull set aside for the ancestors (mombe yevadzimu (Shona)/inkomo yamadlozi (Nguni)) to which traditional rituals of giving to the 
ancestors (kupira mudzimu/ukunikela amadlozi) were performed (Dore, 1970). These rituals were characterised by the pouring of traditional beer (doro remudzimu (Shona)/utshwala bamadlozi (Nguni)) over the bull as a libation for the ancestors, usually accompanied by speech of request (kukumbira kumidzimu/kunevaripasi (Shona)/ukucela amadlozi/kwabaphansi (Nguni)) for the wellbeing of the family. The reaction of the bull to the pouring of the beer onto its head by shaking its head and bellowing was taken as a signal that the ancestors had heard (kubvuma kwevaripasi (Shona)/ukuvuma kwabaphansi (Nguni)).

Burial of a family member is often accompanied by the slaughter of a bull which is then consumed during the funeral ceremony (Bere-Chikara, 1970; Makamure, 1970). It is believed that this beast will accompany the deceased to the next world, the world of the ancestors (Makamure, 1970).

\section{Conclusion}

Indigenous rural communities in southern Africa rely on livestock because of their holistic role enabling them to serve multiple functions that include social, cultural, spiritual, utility, economic and political values. Livestock, as a living currency, provide a means of socio-cultural and ecological resilience that enables indigenous communities to adapt to changing socioeconomic and environmental conditions. Such resilience is sustained through intergenerational learning processes and knowledge transfer. Livestock are an economic asset that does not necessarily have to be translated (exchanged) into monetary currency; they are by themselves an independent and living currency with multiple applications relevant to indigenous community contexts. They are a viable alternative currency to modern monetary currency and there are many culturally significant practices where this living currency cannot be substituted by monetary currency.

Of significance in the recognition of livestock as a living indigenous currency is the knowledge transfer around this cultural heritage and its multiple roles. This implies that the sustaining of the knowledge of livestock as a currency that serves multiple roles within indigenous community contexts occurs through transgenerational cultural education processes. Formal education processes should also play a significant role in dismantling the myth of a single monetary capitalist currency by valuing this living currency as a viable alternative to modern monetary currency, one that is not based on the logic of the capitalist monetary economy and which emphasises the coexistence of plural forms of currency.

Noting the coexistence of plural modes of economy and the current hegemony of modern capitalist monetary economies, it remains to be seen whether indigenous currencies will continue to be sustained. As environmental educators, on one hand, we question the stability and sustainability of monetary economies premised on unsustainable capitalist modes of production that are dependent on continued growth derived from finite Earth's ecosystem resources, which are rapidly being depleted and negatively impacted. On the other hand, we observe the implications of the uncurtailed growth of capitalist economies and related rapid urbanisation and environmental pollution and their concomitant negative impacts on environmental resources upon which indigenous peoples and their indigenous currencies are dependent. 


\section{Notes on the contributors}

\section{Lead author}

Shava, Soul | Department of Environmental Education, University of South Africa (UNISA) ORCID: 0000-0003-4103-0559 | shavas@unisa.ac.za

Soul Shava is an Associate Professor in Environmental Education, Department of Science and Technology Education at UNISA. His research interests are in education for sustainability, indigenous knowledges, decoloniality and Africanisation.

\section{Co-author}

Masuku, Sibongile | Sol Plaatje University, South Africa

ORCID: 0000-0003-4103-0559 | sibongiles.place@yahoo.com

Dr Sibongile Masuku is a lecturer of Museum and Heritage Studies at Sol Plaatje University. History, literature, education, cultural and natural heritage define her work, research interests and passion. Her PhD thesis is a postcolonial exploration of socio-cultural inter-generational learning through cattle as a medium of cultural expression in Mpembeni, KwaZulu-Natal.

\section{References}

Ainslie, A. (Ed.) (2002). Cattle ownership and production in the communal areas of the Eastern Cape, South Africa. Cape Town: Programme for Land and Agrarian Studies.

Bere-Chikara, F. (1970). Cattle: The life blood of Shona society. In C. Kileff \& P. Kileff (Eds), Shona customs: Essays by African writers (pp 20-23). Harare: Mambo Press.

Chang, H., Ngunjiri, F.W. \& Hernandez, K.C. (2013).Collaborative autoethnography. Walnut Cree, CA: Left Coast Press, Inc.

Chireshe, E. \& Chireshe, R. (2010). Lobola: The perceptions of Great Zimbabwe University students. Journal of Pan African Studies, 3(9), 211-221.

Comaroff, J. L. \& Comaroff, J. (1990). 'Goodly beasts, beastly goods': Cattle and commodities in a South African context. American Ethnologist, 17(2), 195-216.

Dei, G.J.S. (2000). Rethinking the role of indigenous knowledge in the academy. International Journal of Inclusive Education, 4(2), 111-132.

Dei, G.J.S., Hall, B.L., \& Rosenberg, D.G. (Eds). (2002). Indigenous knowledges in global contexts: Multiple readings of our world. Toronto: Buffalo, published in association with University of Toronto Press.

De Sousa Santos, B. (2007). Beyond abyssal thinking: From global lines to ecologies of knowledges. Review, XXX (1), 45-89.

Doran, M.H., Low, A.R.C. \& Kemp, R.L. (1979). Cattle as a store of wealth in Swaziland: Implications for livestock development in Eastern and Southern Africa. American Journal of Agricultural Economics, 61(1), 41-47.

Dore, L. (1970). The uses of cattle in Shona society. In C. Kileff \& P. Kileff (Eds), Shona customs: Essays by African writers (pp 24-26). Harare: Mambo Press. 
Foucault, M. (1980). Two lectures. In C. Gordon (Ed.), Michel Foucault: Power/Knowledge: Selected Interviews and Other Writings 1972-1977. New York: Pantheon Books.

Freeman, H.A., Kaitibe, H.A., Moyo, S. \& Perry, P.D. (2008). Designing livestock interventions for emergency situations in southern Africa. ILRI Brief No. 1. Nairobi: ILRI.

Gelfand, M. (1973). The genuine Shona: Survival values of an African culture. Gwelo: Mambo Press.

Gelfand, M. (1979). Growing up in a Shona society: From birth to marriage. Gwelo: Mambo Press.

Gelfand, M. (1981). Ukama: Reflections on Shona and western cultures in Zimbabwe. Harare: Mambo Press.

Guy, J. (1987). Analysing pre-capitalist societies in southern Africa. Journal of Southern African Studies, 14(1), 18-37

Gwaravanda, E.T. \& Masaka, D. (2008a). Epistemological implications of selected Shona proverbs. Centre for Advanced Studies of African Society (CASAS) Occasional Paper 41. Cape Town: CASAS.

Gwaravanda, E.T. \& Masaka, D. (2008b). Shona reasoning skills in Zimbabwe: The importance of riddles. Journal of Pan African Studies, 2(5), 193-208.

Hall, M. (1986). The role of cattle in southern African agropastoral societies: More than bones alone can tell. Southern African Archaeological Society (Goodwin Series 5), 83-87.

Huffman, T.N. (2004). Archaeology of the Nguni past. Southern African Humanities, 16, 79-111.

Jimenez, C.R. (2015). Learning and human dignity are built through observation and participation at work. In M. Correa-Chavez, R. Mejia-Arauz, B. Rogoff (Eds), Advances in child development and behaviour (pp. 289-302). Waltham: Elsevier Academic Press.

Karmin, C. (2008). Biography of the dollar: How the mighty buck conquered the world. New York, NY: Crown Publishing Group.

Magubane, B. (1986). The political economy of the South African revolution. African Journal of Political Economy/Revue Africained'Economie Politique, 1(1), 1-28.

Makamure, D.M. (1970). Cattle and social status. In C. Kileff \& P. Kileff (Eds), Shona customs: Essays by African writers (pp 14-16). Harare: Mambo Press.

Maldonado-Torres, N. (2011). Thinking through the decolonial turn: post-continental interventions in theory, philosophy, and critique - an introduction. Transmodernity: Journal of Peripheral Cultural Production of the Luso-Hispanic World, 1(2), 1-15.

Mangena, T. \& Ndlovu, S. (2013). Implications and complication of bride price payment among the Shona and Ndebele of Zimbabwe. International Journal of Asian Social Science, 3(2), 472-481.

Masuku, L. (1999). The role of indigenous knowledge in/for environmental education:The case of a Nguni history in the schools water action project. Unpublished Masters Thesis, Rhodes University, South Africa.

Masuku,L.S. (2018). Inbetweenness:A postcolonial exploration of sociocultural intergenerational learning through cattle as a medium of cultural expression in Mpembeni, KwaZulu-Natal. Unpublished Doctoral Dissertation, Rhodes University, South Africa.

Masuku van Damme, L.S. \& Neluvhalani, E.F. (2004). Indigenous knowledge in environmental educational processes: Perspectives on a growing research arena. Environmental Education Research, 10(3), 353-370.

Mignolo, W. (2012). Epistemic disobedience and the decolonial option. Transmodernity: Journal of Peripheral Cultural Production of the Luso-Hispanic World, 1(2), 44-66. 
Mphande, L. (1993). Ngoni praise poetry and the Nguni diaspora. Research in African Literatures, 24(4), 99-122.

Mwai, O., Hanotte, O., Kwon, Y. \& Cho, S. (2015). African indigenous cattle: unique genetic resources in a rapidly changing world. Asian Australasian Journal of Animal Science, 28(7), 911-921.

Ndlovu-Gatsheni, S.J. (2015). Decoloniality as the future of Africa. History Compass, 13(10), 485-496.

Ngema, N.M. (2013). The enforcement of the payment of lobolo and its impact on children's rights in South Africa. Potchefstroom Electronic Law Journal, 16(1), 405-425.

Odunbaku, B. (2012). The importance of cowrie shells in pre-colonial Yoruba land South Western Nigeria: Orile-Keesi as a case study. International Journal of Humanities and Social Science, 2(18), 234-241.

Oosthuizen, M.P. (1996). Uchibidolo: The abundant herds. A descriptive study of the SangaNguni cattle of the Zulu people with special reference to colour-pattern terminology and naming-practice. Unpublished Doctoral Dissertation, University of Natal, South Africa.

Park, K.S. (2013). Christian spirituality in Africa: Biblical, historical, and cultural perspectives from Kenya. Eugene, OR: Pickwick Publications.

Schneider, H.K. (1964). A model of African indigenous economy and society. Comparative Studies in Society and History, 7(1), 35-55.

Shava, S. (2000). The use of indigenous plants as food by a rural community in the Eastern Cape: an educational exploration. Unpublished Master's (Education) Thesis, Rhodes University, Grahamstown, South Africa.

Shava, S. (2008). Indigenous knowledges: A genealogy of representation and applications in developing contexts of environmental education and development in southern Africa. Unpublished Doctoral Dissertation, Rhodes University, South Africa.

Shava, S. (2013). The representation of indigenous knowledges. In R.B. Stevenson, M. Brody, J. Dillon \& A. Wals (Eds), International handbook of research on environmental education. New York, NY: Routledge.

Shava, S. (2016). The application/role of Indigenous Knowledges in transforming the formal education curriculum for contextual and epistemological relevance: cases from southern Africa. In V.T. Msila \& M.T. Gumbo (Eds), Africanising the curriculum: Indigenous perspectives and theories (pp. 121-139). Stellenbosch: Sun Press.

Shiva, V. (1993). Monocultures of the mind: Perspectives on biodiversity and biotechnology. London \& New York, NY: Zed Books.

Smith, L.T. (1999). Decolonizing methodologies: Research and indigenous peoples. London: Zed Books.

Tsodzo, T.K.M. (1970). Cattle are our bank. In C. Kileff \& P. Kileff (Eds), Shona customs: Essays by African writers (pp. 17-19). Harare: Mambo Press. 